\title{
OD SUWERENNOŚCI DO WŁADZY POLITYCZNEJ
}

\section{Suwerenność jako zjawisko polityczne}

Suwerenność, jak państwo, jest zjawiskiem politycznym par excellence, nawet jeśli nie mówi się o „suwerenności politycznej”. Nie istnieje inna suwerenność, na przykład ekonomiczna czy kulturowa z racji szczególnego statusu podmiotu zdolnego zdobyć i utrzymać suwerenność. Nawet jeśli czasem błędnie wspomina się o takich formach suwerenności ${ }^{1}$.

Suwerenność zawsze jest atrybutem państwa, czyli efektem mobilizacji politycznej zjednoczenia ludzi. Jednak nie każdej mobilizacji, tylko takiej, która prowadzi do opanowania części wielkiej przestrzeni i przekształcenia jej w terytorium. Jest to mobilizacja zupełnie inna niż mobilizacja zarówno wyborcza, jak i ukierunkowana na incydentalną walkę fizyczną, zemstę czy wykazanie własnej umiejętności uczestnictwa w rywalizacji sportowej.

Innymi słowy suwerenność to, jak wcześniej pokazałem w innej publikacji, wyłącznie atrybut podmiotu zdolnego w warunkach anarchii stworzyć i utrzymać monarchię stanowiącą część składową poliarchii ${ }^{2}$, rozumianej jako system regulacji stosunków i utrzymania hierarchii zjednoczeń ludzi zdolnych działać z powołania i posługiwać się każdym środkiem w celu nie tylko przetrwania, ale także ustanowienie porządku zgodnego z jego wyznawaną wizją - jak się wierzy - ładu oczekiwanego przez boga, przynależnego rasie, klasie lub na przykład narodowi.

Nie istnieje suweren taki, jakim prezentowała go myśl polityczna epoki dynastycznej ${ }^{3}$. Każda z suwerennych potęg politycznych podlega uwarunkowaniom śro-

1 D. Elkins, Beyond Sovereignty. Territory and Political Economy in the Twenty-first Century, Toronto 1995; A. Bógdał-Brzezińska, Międzynarodowe struktury wiedzy i innowacji - mechanizmy zmiany, aktualne trendy i uczestnicy, (w:) E. Haliżak (red.), Geoekonomia, Warszawa 2012, s. 163-184.

2 R. Skarzyński, Anarchia i policentryzm. Elementy teorii stosunków międzynarodowych, Białystok 2006, s. 259-368.

3 J. Bodin, Sześć ksiąg o Rzeczypospolitej, Warszawa 1958, s. 88 i 91; E. de Vattel, Prawo narodów, czyli zasady prawa naturalnego zastosowane do postępowania w sprawach narodów i monarchów, Warszawa 1958, t. II, s. $64-70$. 
dowiskowym, a o jej losie ostatecznie rozstrzyga instytucja układu sił. Dostępna nam wiedza historyczna ${ }^{4}$ dowodzi, że nikt nie ujdzie jej wyrokom, nawet jeśli doszedł do pozycji pozwalającej określać się jako imperium.

\section{Rozumienie pojęcia suwerenność}

Pojęcie suwerenność, rozumiane zgodnie ze stanem współczesnej wiedzy z zakresu nauk społecznych, zakłada obecność potęgi, czyli zespołu sił w działaniu, generowanych przez specyficzny podmiot złożony z ludzi zdolnych kreować lub przekształcać dostępną im rzeczywistość. $Z$ istnieniem potęgi zawsze łączy się chęć rozwoju, ekspansji i panowania, a tym samym gotowości do rywalizacji, nawet walki, którą prowadzi się w starciu z inną potęgą lub kilkoma.

Dlatego obecność potęgi dysponującej atrybutem suwerenności możliwa jest tylko w wyniku występowania innych tego typu podmiotów, wchodzących we wzajemne interakcje i wspólnie tworzących układ sił. Faktycznie zaś instytucję układu sił, czyli mechanizm regulujący ich wzajemne relacje, przede wszystkim zaś status każdej z nich, gdy najczęściej planują one uzyskanie przewagi, hegemonię lub nawet dominację.

Terytorialne potęgi polityczne powstają i upadają, a instytucja układu sił określająca ich położenie funkcjonuje nieprzerwanie i przesądza o tym, która $\mathrm{z}$ nich przetrwa, która zaś stanie się łupem rywali ${ }^{5}$. W obrębie tych terytorialnych potęg politycznych kształtuje się władza polityczna, zwykle nazywana władzą państwową, na różne sposoby, zależnie od wykształconych w czasie mechanizmów rekrutacji elity w sieciach stosunków społecznych.

W praktyce, w świecie przyrody i stosunków społecznych, gdzie występuje wiele zależnych od siebie zjawisk, w tym ośrodków generujących energię, działają złożone zespoły sił, a ich występowanie pociąga za sobą nierzadko szerokie zmiany. Trudno przyjąć, że nikt owych sił ostatecznie nie kontroluje z zewnątrz, a człowiek jest wystawiony na konieczność walki w warunkach działania wielkich żywiołów, w niej, pozbawiony opieki boskiej, zdany jest na siły swoje i sojuszników. Musi działać nie w warunkach równowagi sił, ale zmiennych układów sił. Do takich wniosków prowadzi elementarna analiza historii ludzkich społeczeństw ${ }^{6}$, trudna jednak do przyjęcia przez marzycieli poszukujących stabilności i bezpieczeństwa. Tym bar-

$4 \quad$ Tak znakomicie zebrana między innymi w książkach S. Eisenstadt, The Political System of Empires. New York 1963; B. de Jouvenel, On Power. Its Nature and the History of Its Growth, Boston 1962; I. Wallerstein, Geopolitics and Geoculture. Essays on the Changing World System, Cambridge 1992; F. Braudel, Morze Śródziemne i świat śródziemnomorski w epoce Filipa II. T. I-II, Warszawa 2004. Jak pokazał to ponownie na bogatym materiale historycznym L. Benton, A Search for Sovereignty. Law and Geography in European Empires 1400-1900, Cambridge 2009, s. 40-161.

6

Do której materiałów dostarczają niezliczone badania reprezentantów różnych nauk społecznych. Np. M. Bloch, Społeczeństwo feudalne, Warszawa 1981; P. Kennedy, Mocarstwa świata. Narodziny - rozkwit - upadek. Przemiany gospodarcze i konflikty zbrojne w latach 1500-2000, Warszawa 1994. 
dziej, kiedy oni działają w imieniu władzy politycznej, przekonani o jedności świata społecznego.

Poza siłami natury nie istnieje potęga $\mathrm{w}$ przestrzeni dostępnej naszemu gatunkowi, która nie miałaby charakteru społecznego, a więc nie byłaby efektem grupowania się ludzkich zbiorowości. Oznacza to, że funkcjonowanie społeczeństw skupiających osobniki naszego rodzaju należy wyjaśniać w kontekście rzeczywistych sił, mających określone, dające się zlokalizować pochodzenie i działających zgodnie z mechanizmami przesądzającymi o ich poczynaniach. Abstrakcyjne pojęcia czy koncepcje, nie znajdujące odniesienia przyrodniczego i społecznego, nie mogą być stosowane, ponieważ nic nie mówią o rzeczywistości. One są wyłącznie doktrynami, a nie teoriami.

Potęgi mają charakter społeczny, gdyż wyłaniają się w wyniku skupiania i integrowania zbiorowości ludzkich, a one wymagają zaopatrzenia w odpowiednie zasoby, aby mogły funkcjonować, reprodukować się i działać w wielkiej przestrzeni. Wszystko to dzieje się zawsze w warunkach konkretnej niszy ekologicznej, czyli wydzielonego środowiska przyrodniczego. $Z$ niego życie zorganizowane społecznie czerpie niezbędne mu zasoby i przetwarza je na energię.

Wszystkie potęgi, także suwerenne, aspirujące do władania wielką przestrzenią, tylko w ten sposób generują specyficzne dla siebie siły i przejawiają konkretne zdolności przekształcania świata. Z jednym wyjątkiem: doktryny, która mobilizuje umysły członków zbiorowości do wspólnego działania w poczuciu prawowitego pochodzenia, związanych z nim uprawnień, a także energii moralnej. Ona pozwala aspirować do wszystkiego, co zewnętrzne, obracać to we własny środek, a nawet niszczyć w aktach ideologicznego upojenia.

Jedną z takich doktryn jest tradycyjna doktryna suwerenności, która za pomocą apriorycznych twierdzeń tworzy w ludzkiej świadomości poczucie wielkości, stabilności, a nawet prawo panowania nad światem, czy to z ramienia boga, rasy, klasy, czy narodu. Taka wykładnia ,,prawdy” nie mówi nam jednak niczego istotnego o rzeczywistym funkcjonowaniu suwerennej potęgi, nie działającej w imieniu ośrodka wyższego, ale na własne ryzyko w sieciach stosunków społecznych, towarzyszących im układach sił i niszy przyrodniczej.

Doktryna jest jednak ważna dla funkcjonowania potęgi, zwłaszcza fundamentalna dla potęgi mającej ambicje operowania w wielkiej przestrzeni. Aktywność potęgi wymaga zjednoczenia ludzi w całość społeczną dysponującą siłą moralną, która może się wykazać nieprzypadkowym pochodzeniem i uprawnieniami do działania. Także działania polegającego na korzystaniu z ofiary własnych członków, jak i specyficznego traktowania wrogów, których się eksploatuje, a nawet zabija nie w aktach zbrodni, tylko uzasadnionego, koniecznego postępowania. Prawo do tego daje doktryna, ponieważ ona czyni podmiot polityczny nieprzypadkowym, dowodząc jego praw, pochodzących od boga, rasy, klasy czy narodu. Tylko w ten sposób istnieje 
podmiot przygotowany do posługiwania się wszystkimi środkami, także ludźmi gotowymi ofiarować mu swoje życie.

Doktryna suwerenności powinna być badana nie jako teoria naukowa, ale jako jeden ze środków potęgi, która walczy o porządek dostępnego jej świata.

\section{Suwerenność, terytorium i władza polityczna}

Zjednoczenie ludzi uzyskuje i zachowuje suwerenność generując wymaganą potęgę w układach sił rozstrzygających o zależnościach kształtujących się w wielkiej przestrzeni, gdzie zostaje określone władanie konkretnymi terytoriami i wyznacza się pomiędzy nimi granice.

Suwerenność jest zawsze związana z terytorium. Jest ona atrybutem potęgi politycznej, ponieważ wyłania się w układach sił grupujących podmioty z powołania walczące o porządek świata każdym środkiem i w nich jest realizowana. Jednak nie każdej potęgi politycznej, ale wyłącznie dysponującej terytorium, na którym panuje.

Suwerenność nie jest atrybutem rodu dynastycznego czy partii politycznej. Ona jest atrybutem państwa, którym włada na przykład dynastia lub partia. Chociaż jest możliwa tylko w efekcie użycia środków materialnych, jej fundamentem jest wizja, stanowiąca wytwór ludzkiego umysłu i pozwalająca odróżnić to, co uzasadnione od tego, co przypadkowe, to, co prawomocne od tego, co nielegalne.

Ośrodek postrzegany jako suwerenny, niezależnie czy będzie to dynasta przewodzący wielkiemu rodowi, grupującemu na określonym terytorium wokół siebie zbiorowości ludzkie, czy rząd nowoczesnego, demokratycznego państwa, jednoznacznie określonego granicami, musi dysponować wizją uzasadniającą jego pozycję i przypisane jej uprawnienia. One nie mogą być pojmowane jako przypadkowe, lecz muszą być odbierane przez ludzi jako konieczne, nieuchronne, niepodważalne, ostateczne i wieczne.

Układ sił powstaje w wyniku zderzenia sił generowanych przez tworzące go podmioty społeczne, podmioty z nimi związane, a także siły przyrody, które pochodzą spoza niego, lecz oddziałują na uczestników.

Suwerenność jest skutkiem wyłonienia potęg posiadających zdolności do przekształcania rzeczywistości w układach sił poliarchii, czyli w systemie, który tworzą owe potęgi w środowisku. W tym środowisku realizują one własne ambicje i ono nie jest wobec nich neutralne, ale oddziałuje na podmioty polityczne, zwiększa lub obniża szanse przetrwania i realizacji ich zamierzeń, już tylko dlatego, że rozmaite zjednoczenia ludzi obdarza zróżnicowanym dostępem do zasobów nadających się do przetwarzania na energię.

Układ sił suwerennych potęg wielkiej przestrzeni kształtuje się i funkcjonuje w środowisku, lecz ostatecznie ,spoczywa” na jego uczestnikach. Sam nie tylko nie jest porządkiem, ale nawet nie potrzebuje uzasadnienia czy jakiejkolwiek podbu- 
dowy normatywnej. Do jego powstania konieczne są wyłącznie istniejące na własne ryzyko podmioty dysponujące statusem politycznym, oddzielnymi terytoriami i zdolne wchodzić we wzajemne stosunki.

Taki układ sił jest czymś odrębnym i odmiennym od porządku, także wtedy, gdy w dowolnej przestrzeni obie te instytucje istnieją równocześnie. Powstaje on przecież żywiołowo, samorzutnie i nie występują uniwersalne wzorce, wedle których mógłby się kształtować. Nikt nie jest w stanie ani go samodzielnie powołać, ani znieść, może co najwyżej przyczynić się do jego przeobrażenia albo upadku, nie tylko przez rozwój własnej potęgi, ale również drogą samounicestwienia ${ }^{7}$.

Układ sił kształtuje się jako wypadkowa zdolności przeobrażania rzeczywistości przez jednych i słabości w tej dziedzinie innych. Nowe konfiguracje w jego ramach powstają nie tylko przez wyodrębnianie się niezwykłych, wyróżniających się swoimi rozmiarami, skoncentrowanych potęg, ale także przez osłabienie i rozpad dotychczas istniejących. Dlatego taki układ nie zmierza i nie może zmierzać do równowagi. Cechuje go zmienność, która powoduje, że los każdego z jego uczestników jest niepewny. Ostatecznym wyznacznikiem aktualnego stanu układu sił są ambicje największych potęg, które dążą do potwierdzenia przewagi, a następnie uzyskania hegemonii lub nawet do dominacji.

Układ sił utrzymuje zgrupowane za swoim pośrednictwem podmioty w systemie wzajemnych zależności, regulując ich zachowania i stosunki zachodzące pomiędzy nimi. Jest ważną instytucją nadającą tym podmiotom kształt i kierunek działania, a przede wszystkim określa ich miejsce w hierarchii. Tym samym układ sił wyznacza status każdego jego uczestnika, rozstrzyga o tym, kto dominuje, kto przewodzi, kto jest neutralny, albo komu przypadła rola satelity.

Układ sił tworzony przez podmioty polityczne może rozciągać się w wielkiej przestrzeni i funkcjonować w długim czasie, czyli obejmuje zbiór terytoriów i funkcjonuje w okresie życia kolejnych pokoleń ludzi. Zależy to tylko od zwartości jego uczestników i osiąganej przez nich wielkości, co natychmiast ujawnia się w środkach pozostających w ich dyspozycji.

Szczególna pozycja podmiotów politycznych nie jest dziełem przypadku, ale skutkiem konieczności. W wielkiej przestrzeni i długim czasie dominująca rola musi przypaść układowi sił grupującemu podmioty zdolne posługiwać się wszystkimi dostępnymi siłami, także moralnymi, ponieważ dzięki nim możliwe jest działanie środkami prawdziwie ostatecznymi, wynikającymi z masowego użycia ludzkiego życia jako narzędzia do walki. Tak działa selekcja. Ona promuje te zjednoczenia ludzi, które nie tylko kumulują coraz większa zasoby, ale także rozwijają zdolność ich skoordynowanego wykorzystania do oddziaływania na swoje otoczenie.

Ostatecznie promowane są te podmioty, które dysponują specyficznymi siłami: zgodnymi z wymaganiami układów sił wielkiej przestrzeni. Każdy układ sił żąda 
od jego uczestników dostosowania do własnych wymagań. Określa on cechy, jakie jego uczestnicy powinni przejawiać, aby z niego nie wypaść, co prowadzi do przejęcia ich środków przez zdolnych w nim się utrzymać. Pokornych, uważnych, giętkich promuje, pozwala im się rozwinąć, dumnych, lekceważących zagrożenia, sztywnych - karze, wymuszając zmiany. Całkowicie niepokornych, nieposłusznych, niepoprawnych, rozrzutnych i dumnych skazuje na likwidację. Tym bardziej kiedy utracili kontrolę nad zasobami, pozbyli się ich czy je roztrwonili.

Ponieważ ostatecznym układem sił w ramach gatunku ludzkiego jest układ sił politycznych, nie moralność, ale siła moralna odgrywa ogromną rolę. Tylko dlatego, że każdy podmiot polityczny działa w poczuciu nadzwyczajnego powołania do realizowanego przez siebie dzieła, czyli zjednoczeni w nim ludzie wierzą, że działają $\mathrm{z}$ woli boga, rasy, narodu, wspólnoty narodów, praw człowieka czy innego odniesienia, takiego jednak, które czyni jego misję najwyższą, ostateczną i daje prawo do panowania nad światem.

Układ sił nie zna uczuć, emocji i dlatego jest bezwzględnym i obiektywnym sędzią. Od jego wyroków nie ma odwołania, ponieważ nie istnieje instancja zdolna je rozpatrzyć. Układ sił potęg politycznych tworzy w obrębie gatunku ludzkiego trybunał ostateczny, ostateczny w dosłownym znaczeniu, ponieważ mamy do czynienia z układem sił podmiotów zdolnych z powołania uderzyć każdym środkiem.

Układ sił poliarchii pełni wiele funkcji, szczególnie jeśli działa w wielkiej przestrzeni i długim czasie. On jest sędzią suwerennych potęg w tym sensie, że ostatecznie rozstrzyga o ich pozycji w hierarchii, a także o tym, która z nich istnieje dalej, która zaś zostaje obrócona w niebyt.

Faktycznie jednak układ sił poliarchii działa subtelnie, nierzadko w sposób wyspecjalizowany i jest przewidywalny dla tych, którzy rozumieją zasady jego funkcjonowania. Najważniejsze funkcje tej instytucji ujawniają się w czynnościach specyficznych dla promotora, egzekutora i selekcjonera. Przez nie on kształtuje podmioty $\mathrm{w}$ nim uczestniczące, określa ich pozycję $\mathrm{w}$ hierarchii i realizuje swoje najwyższe powołanie: sędziego, zdolnego decydować o tym, które ze społecznych zjednoczeń zginą, którym zaś dane będzie przetrwać i realizować własne zadania, związane z pozyskiwaniem zasobów, przetwarzaniem ich na energię, generowaniem sił do walki i budowaniem własnego, partykularnego porządku.

Wszelkie życie istnieje bowiem tak, że porządek nie tylko w postaci prostych zależności opartych na regulacji relacji społecznych, tym bardziej zaś porządek normatywny, przychodzi mu z trudem. Nic tutaj nie jest dane, ale musi być wytworzone, potem zaś podlega selekcji i tylko byty zdolne wypełniać ważne funkcje wykazują się zdolnością reprodukcji w czasie.

Układ sił w stosunkach międzynarodowych w dosłownym znaczeniu przesądza o zachowaniach jego uczestników, w zależności od wielkości ich potęgi i sposobu jej używania. Reguły i normy mają tu drugorzędne znaczenie. Zwykle są traktowane jako środki do celu. Każdy podmiot próbuje rywalom narzucić własne zasady i sys- 
tem prawa i, jeśli tylko jest dostatecznie potężny, może przyjmować, odrzucać czy kształtować reguły i normy zgodnie z własną wolą. W tym wyraża się pełnia jego suwerenności, która w takim zakresie na przykład nie przysługuje satelitom mocarstw, podmiotom z samej swej natury zależnym.

Uczestnicy wchodzący w ramach układu sił we wzajemne kontakty zbierają doświadczenia, a one pokazują co jest korzystne, co zaś niebezpieczne i może przynieść szkody. Określa, czego strony mogą się wzajemnie od siebie spodziewać i do jakich świadczeń sami są wobec nich zobowiązani. Uświadamia, kiedy lepiej ustąpić silniejszemu, kiedy zaś walka z nim jest nieuchronna. Dlatego mniejsi na co dzień nie przeciwstawiają się większym, tworzone są reguły, a nawet są przyjmowane normy i wyniszczające zmagania zostają ograniczone.

Każdy podmiot polityczny niesie swoją kulturę, własne wyznanie, wizję, pewniki i system prawa, który stara się narzucić innym, jeśli tylko dysponuje do tego odpowiednimi środkami. Zawsze może wyłonić się podmiot, który poczuje się zdolny przekreślić ustalone zasady i system prawa, a nawet wiarę i rzucić wyzwanie do walki przy użyciu nowej wizji. Zwłaszcza jeśli daje mu ona przewagę, ponieważ uczuciowo jednoczy ludzi.

W układzie sił nikt nie jest do końca przegrany, jeśli tylko istnieje. Nawet uczestnicy zepchnięci na margines i zmuszeni do posłuszeństwa, dysponują przecież nadal pewnymi zasobami, których znaczenie w kolejnych konfiguracjach stosunków może wzrosnąć i zrodzić nowe napięcia, motywując do walki. Takie całości stosunków społecznych pojawiały się wielokrotnie w dziejach gatunku ludzkiego, zwłaszcza kiedy dochodziło do destabilizacji stosunków społecznych. Wyposażone w nową wiarę, jak wcześni chrześcijanie, prawosławni, katolicy, protestanci, muzułmanie, ale także liberałowie, bolszewicy, komuniści, faszyści, zmieniali świat i rządzący nim układ sił największych potęg.

Najbardziej żarłocznymi spośród potęg politycznych tworzących układy sił poliarchii, były szybko powstające, dynamiczne imperia i mocarstwa. Czasem kształtowały się z zupełnie małych całości, jak starożytna Macedonia, plemiona żyjące na mongolskim stepie czy niewielki brandenburski elektorat, zdolny przekształcić się w Królestwo Pruskie, a potem w II Rzeszę Niemiecką. Dlatego ujęcie instytucji układu sił w znaczeniu aksjologicznym czy normatywnym jest niewystarczające do zrozumienia funkcjonowania potęgi politycznej w stosunkach społecznych, w szczególności zaś w stosunkach międzynarodowych współczesnej poliarchii.

Układ sił terytorialnych podmiotów politycznych jest jedyną rzeczywistą instytucją wielkiej przestrzeni, regulującą funkcjonowanie gatunku ludzkiego, która, chociaż jest tworzona przez byty o statusie potęg zdolnych wykorzystywać wszelkie środki, nie podlega kontroli z ich strony w całości. Terytorialne podmioty polityczne mogą tylko na nią wpływać zależnie od sił pozostających w dyspozycji każdego z nich, uruchamianych nie dowolnie, ale w systemie wzajemnych zależności. 
Wprawdzie imperia próbują upowszechniać wrażenie, że one kontrolują każdą z obecnych siły, ale nie ma to nic wspólnego z rzeczywistością. Często do zdobycia wysokich pozycji wykorzystuje się sojusze, a takie układy są przecież wyrazem zależności. Wprawdzie imperia u szczytu potęgi nie mają sojuszników, jednak nawet one podlegają wielu determinantom, chociażby związanym z określaniem możliwych do osiągnięcia celów, rozsądnym gospodarowaniem zasobami czy posługiwaniem się przemocą. Gdy wojna wydaje się najłatwiejszym do zastosowania środkiem podczas realizacji interesów, trwonienie zasobów przychodzi bardzo łatwo. Dlatego nawet imperia są uwikłane w zależności i podlegają bezwzględnej ocenie przez układ sił, który narzuca ramy ich działaniom i w końcu doprowadza do upadku każdy terytorialny podmiot polityczny.

Układ sił, ostatecznie jako całkowicie samodzielny sędzia, sam nadzoruje swoich uczestników, czyni to stale i bez ograniczeń, wyłącznie przy ingerencji sił środowiska przyrodniczego. Czasem, zwłaszcza kiedy w tym układzie wyłaniają się specyficzne zależności i sojusze, promuje nieliczne potęgi, by potem skazać je na zagładę. Im te są większe, tym bardziej bywa wobec nich bezwzględny.

\section{Władza polityczna i porządek}

Układ sił poliarchii utrzymuje terytorialne całości społeczne w czasie i reguluje ich pozycję w przestrzeni, w hierarchii politycznej, która zdaje się przypominać porządek ostateczny, ale, o dziwo, występujący tylko w danym momencie. Potem porządek ten szybko się załamuje, by dać miejsce kolejnemu ładowi, który okazuje się także zmiennym układem. Warto bliżej zastanowić się czym jest to, co wielu jawi się jako porządek, ponieważ z pewnością nie jest tym, co obecnie rozumie się przez porządek międzynarodowy czy wspólnotę narodów. Nie istnieje przecież ani jako efekt porozumienia stron, ani zastosowania norm do regulacji chaosu.

Nie zrozumiemy działania poliarchii, jeśli nie wyjaśnimy różnic pomiędzy porządkiem panującym wewnątrz monarchii, na ich terytorium i tym, co pozostaje na zewnątrz nich. Co wykazuje cechy anarchii, nawet jeśli okresowo relacje monarchii charakteryzuje daleko idące ułożenie. Gdy zamieszkujący je ludzie wierzą w stabilizację stosunków państw i nawet mówią o równowadze układu sił.

System polityczny grupujący państwa charakteryzuje nieobecność ośrodka zdolnego do stanowienia prawa i jego egzekucji, jak ma to miejsce w obrębie porządku terytorialnego zjednoczenia politycznego.

To, co często widzi się jako porządek i na przykład współcześnie nazywa ,,porządkiem międzynarodowym” albo „wspólnotą państw”, oznacza tu wyłącznie strukturę wzajemnych zależności terytorialnych podmiotów politycznych, czyli 
państw, przy oddziaływaniu innych podmiotów ${ }^{8}$ i środowiska naturalnego. Ta struktura narzuca jej uczestnikom pewne zachowania, zabrania innych i bardziej powinna się kojarzyć z mechanizmem utrzymywania swoistej karności w kręgu niesfornych podmiotów, wyrażających ogromne ambicje, artykułujących niespotykane gdzie indziej interesy i gotowych rzucać do walki wielkie środki.

Normy są pisane, a raczej wyznaczane, w zależności od woli potęg dominujących w układzie sił poliarchii. Znajdują swoje odzwierciedlenie nie w jednolitym akcie konstytucyjnym, ale w traktach międzynarodowych, negocjowanych przede wszystkim po zakończeniu wielkich konfrontacji militarnych ${ }^{9}$, gdy ludzie są poruszeni ogromem zbrodni i strat, a przede wszystkim kiedy doszło do załamania części starych potęg i na ich miejsce wyrosły nowe.

Taki, nie porządek, ale system utrzymania karności, zostaje zawsze określony przez stosunek sił. Wartości i wizje pełnią w nim zupełnie inną funkcję, aniżeli w przypadku państwa. One są tylko specyficznymi środkami, jednymi z wielu, za pomocą których oddziałuje się na rzeczywistość, aby mobilizować ludzi do świadczeń materialnych na rzecz państwa, ofiarowania życia w walce czy też narzucania własnych interesów rywalom, czyli obcym, którzy konkurują o zasoby środowiska i wiedzę technologiczną.

Porządek istnieje tylko w obrębie granic monarchii (obecnie rozumianej jako państwo), gdzie przezwyciężono anarchię doprowadzając do wyłonienia ośrodka dysponującego monopolem legalnej przemocy, czyli władzy politycznej, nazywanej najczęściej władzą państwową. Takie terytorialne zjednoczenia ludzi w efekcie wchodzenia we wzajemne stosunki tworzą system relacji regulowany generowanymi przez nich siłami. Ten układ sił przesądza o kształcie i losach poliarchii, czyli systemie monarchii funkcjonujących w warunkach anarchii, gdy relacje pomiędzy podmiotami określa bieżąca konfrontacja sił.

Podstawową cechą układu sił jest naturalna nierównowaga, ujawniająca się zróżnicowaniem sił podmiotów w nim zgrupowanych, ich słabnięciem, wzrostem, uzyskiwaniem przewagi, a także jej utratą. Zwykle jednak nie taka nierównowaga, która prowadzi do jego szybkiego zniszczenia, ale wymusza mniej lub bardziej powolne zmiany w długim czasie, czyli w okresie życia kolejnych pokoleń ludzi. Tempo tych zmian bywa różne. Potrafią się one rozciągać na setki lat i zawsze są związane ze zdolnościami reprodukcji i przeobrażeń podmiotów społecznych generujących siły i utrzymujących w ten sposób ich specyficzny układ w przestrzeni poliarchii.

Szczególnie gospodarczych, przestępczych i zajmujących się kreowaniem, a potem upowszechnianiem symboli. Z ich dokonań podmioty polityczne mogą czerpać, wykorzystując je jako środek własnej polityki. Równocześnie najbardziej wpływowe spośród nich modyfikują decyzje i działania rządów państw i kierownictw partii politycznych.

9 Obecnie, po wystąpieniu Edwarda Snowden, konfrontacje nabierają innego charakteru. Ich efektem będą jednak nowe regulacje prawne. 
Przykładem takiego układu sił może być europejski układ dynastyczny, funkcjonujący od późnego średniowiecza po XX w., kiedy to ludzie grupowali się wokół władców zdolnych przekazywać swe uprawnienia przez pokolenia swoim potomkom, symbolizującym boski porządek świata ${ }^{10}$. Faktycznie zaś skupionych wokół rodów, które reprodukowały się przez stulecia i tym samym podtrzymywały nie tylko instytucję władzy, ale także konkretne układy sił społecznych. Na terytoriach objętych ich uprawnieniami suwerennymi, jak i pomiędzy nimi, w wielkiej przestrzeni poliarchii.

Ten układ sił zmieniał się, ponieważ pojawiały się nowe polityczne potęgi terytorialne ${ }^{11}$, a wiele $\mathrm{z}$ istniejących słabło. Był on jednak homogeniczny aż do momentu, gdy pojawiły się wyzwania stawiane przez podmioty wyznające ideały demokratyczne.

Suwerenność oznaczała tu nie jakąkolwiek niezależność, ale była skutkiem zdolności utrzymania się w konkretnym układzie sił. Z niego nie można było wystąpić, nie sposób też było istnieć obok niego. Trzeba było w nim walczyć o przetrwanie i prawo reprodukcji, a uzyskiwało się to niepoddając się woli rywali i zapewniając sobie dostęp do zasobów, technologii i utrzymując zdolność przetwarzania energii w koniecznym zakresie.

Układ sił cechuje nierównowaga, która ujawnia się w zmienności samego układu sił, jak i całej poliarchii, w sensie jej sieci stosunków społecznych i charakterystycznych dla niej struktur społecznych. W układach sił wielkiej przestrzeni, tym bardziej z racji liczby i zróżnicowania podmiotów działających na siebie, nie sposób mówić nawet tylko o stanach zbliżonych do równowagi sił. Nawet w sensie braku przewagi pozwalającej jednym państwom ingerować w sprawy innych państw. Takie zjawisko zawsze ma miejsce w efekcie zróżnicowania generowanych przez nie sił.

Układ sił jakiejkolwiek poliarchii, czy regionalnej czy globalnej, cały czas się przeobraża i nie ma sposobu zapanowania nad nim nie tylko do końca, ale w znacznej części, nawet jeśli pojawiają się plany dominacji charakterystyczne na przykład dla imperiów, gdy chcą one panować nad całym znanym sobie światem. Także wówczas, jeśli jedno z nich osiąga jakiś wyjątkowy stan, ujawniający się w niespotykanym dotychczas poziomie dominacji, to jest on przejściowy. Wcześniej czy później ujawniają się siły zmieniające jego nadrzędną pozycję i rozpoczyna się walka, która ostatecznie niszczy potęgę dominującą, otwierając szanse przed nowymi, dotychczas niedocenianymi uczestnikami układu sił.

Układ sił istnieje w czasie, ale to nie oznacza, że on po prostu trwa. Kiedy funkcjonuje, stale przeobraża się i zmierza do stanu odmiennego, aniżeli aktualny. Nikt nie zmieni mechanizmu przekształceń. Może jedynie swoją skuteczną polityką przyspieszyć pewne przeobrażenia, a inne nieco wyhamować. Charakter i kierunek 
kluczowych zmian w wielkiej przestrzeni i czasie życia kolejnych generacji ostatecznie nie zależą bowiem od decyzji przywódców i elit, ale od zjawisk zachodzących w sieciach stosunków społecznych, gdzie realizują swoje interesy i ścierają się miliony ludzi i ich niezliczone zjednoczenia różnej rangi, podejmujące w rozmaitej skali działania związane z tworzeniem wartości, symboli, dążeniem do zysku, budowaniem struktur legalnych i przestępczych czy rozwijaniem i niszczeniem ludzkich związków, tak lokalnych, regionalnych, jak i wykraczających poza te ramy.

Układy sił określają nie tylko cechy małych podmiotów. W wielkiej przestrzeni kształtują się układy sił rozstrzygające o specyfice wszystkich operujących tu zjednoczeń ludzi. Także tych poczuwających się do misji ustanowienia powszechnego porządku w poczuciu powołania do tego zadania przez boga, rasę, klasę i naród. Oznacza to, że układy sił wielkich potęg, rywalizujących ze sobą w systemie poliarchii, przesądzają o istnieniu i funkcjonowaniu władzy politycznej w każdej jej postaci.

\section{BIBLIOGRAFIA}

Benton Lauren. 2009. A Search for Sovereignty. Law and Geography in European Empires 1400-1900, Cambridge Cambridge University Press.

Bloch Marc. 1981. Społeczeństwo feudalne. Warszawa: Państwowy Instytut Wydawniczy.

Bodin Jean. 1958. Sześć ksiąg o Rzeczypospolitej. Warszawa: Państwowe Wydawnictwo Naukowe.

Braudel Ferdynand. 2004. Morze Śródziemne i świat śródziemnomorski w epoce Filipa II. Warszawa: Książka i Wiedza.

Elkins David. 1995. Beyond Sovereignty. Territory and Political Economy in the Twenty-first Century. Toronto: University of Toronto Press.

Jouvenel Bertrand de. 1962. On Power. Its Nature and the History of Its Growth. Boston: Viking Press.

Kennedy Paul. 1994. Mocarstwa świata. Narodziny - rozkwit - upadek. Przemiany gospodarcze i konflikty zbrojne w latach 1500-2000, Warszawa: Książka i Wiedza.

Skarzyński Ryszard. 2006. Anarchia i policentryzm. Elementy teorii stosunków międzynarodowych. Białystok: Wydawnictwo Wyższej Szkoły Ekonomicznej.

Vattel Emerich de. 1958. Prawo narodów, czyli zasady prawa naturalnego zastosowane do postępowania w sprawach narodów i monarchów. Warszawa: Państwowe Wydawnictwo Naukowe.

Wallerstein Immanuel. 1992. Geopolitics and Geoculture. Essays on the Changing World System. Cambridge: Cambridge University Press. 


\section{FROM SOVEREIGNTY TO POLITICAL POWER}

Every political union with the character of a political-territorial power, functions in conditions of disorder in which it establishes its own centres of force, law and government. Over time such a political union begins to possess a monopoly of legal force, and its existence is secured when it receives the recognition of other units of the same type. In this way polyarchy, or multi-government arises - a collection of monarchies functioning in the anarchic conditions of the area in which there is no supreme centre and mutual relations are formed by participants among themselves and at their own risk.

Słowa kluczowe : suwerenność, poliarcha, włądza polityczna, państwo Keywords: Sovereignty, polyarchy, political power, state 